\title{
Green synthesis of tri/tetrasubstituted $1 H$-imidazoles and 2,3-dihydroquinazolin-4(1H)-ones using nano aluminium nitride as solid source of ammonia
}

\author{
MARYAM HAJJAMI*, ARASH GHORBANI-CHOGHAMARANI, ZAKIEH YOUSOFVAND and \\ MASOOMEH NOROUZI \\ Department of Chemistry, Faculty of Science, Ilam University, P.O. Box 69315516, Ilam, Iran \\ e-mail: mhajjami@yahoo.com; m.hajjami@ilam.ac.ir
}

MS received 17 December 2014; revised 19 March 2015; accepted 28 March 2015

\begin{abstract}
A simple, green and cost-effective protocol was achieved for the synthesis of tri/tetrasubstituted$1 \mathrm{H}$-imidazoles and 2,3-dihydroquinazolin-4 $(1 \mathrm{H})$-ones using nano aluminium nitride. The reaction was carried out under catalyst-free conditions and the products were isolated in good to excellent yield.
\end{abstract}

Keywords. Imidazoles; 2,3-dihydroquinazolin-4(1H)-ones; nano aluminium nitride; multicomponent; one-pot.

\section{Introduction}

Nitrogen-heterocyclic compounds (NHCs) are produced for a variety of applications, including pharmaceuticals, cosmetics, pesticides, disinfectants, agrochemicals, dyestuffs and antifreeze. ${ }^{1}$ In particular, derivatives of imidazoles and hydroquinazolins are used as reagents in industry. ${ }^{2}$ The five-membered imidazole ring is one of the important substructures found in a large number of natural products and pharmacologically active heterocyclic compounds. ${ }^{3}$ The members of this class of compounds are known to possess NO synthase inhibition and antifungal, antimycotic, antibiotic, antiulcerative, antibacterial, antitumor, and CB1 receptor antagonistic activities. ${ }^{4}$ Among the imidazoles, 2,4,5-triphenylimidazoles can be used as light-sensitive materials in photography, as inhibitors of IL-1 or p38 MAP kinase, fungicides and herbicides and plant growth regulators. ${ }^{5,6}$

There are numerous methods in the literature for the synthesis of highly substituted imidazoles: condensation of 1,2-diones, aldehydes, primary amines and ammonia in the presence of several catalysts such as $\mathrm{FeCl}_{3}$. $6 \mathrm{H}_{2} \mathrm{O},{ }^{7}$ ionic liquids, ${ }^{8} \mathrm{~K}_{5} \mathrm{CoW}_{12} \mathrm{O}_{40} \cdot 3 \mathrm{H}_{2} \mathrm{O},{ }^{9} \mathrm{HClO}_{4}$ $\mathrm{SiO}_{2}{ }^{10} \mathrm{NaH}_{2} \mathrm{PO}_{4},{ }^{11}$ heteropolyacids, ${ }^{12} \mathrm{InCl}_{3}-3 \mathrm{H}_{2} \mathrm{O},{ }^{13}$ Bronsted acidic ionic liquid, ${ }^{14} \mathrm{MCM}-41$ or $\mathrm{p}-\mathrm{TsOH} .{ }^{15}$ In addition, they can also be accessed by hetero-Cope rearrangement, condensation of a 1,2-diketone with an aryl nitrile and primary amine under microwave irradiation, and $\mathrm{N}$-alkylation of trisubstituted imidazoles. ${ }^{16}$

*For correspondence
Many of the synthetic methods for imidazoles suffer from one or more disadvantages such as low yields, harsh reaction conditions, prolonged time period and application of hazardous and often expensive acid catalysts and expensive catalysts long reaction times. ${ }^{17}$ Moreover, the synthesis of these compounds is usually carried out in polar solvents such as ethanol, methanol, acetic acid, dimethylformamide (DMF), and dimethylsulfoxide (DMSO), leading to complex isolation and recovery procedures. ${ }^{14}$

2,3-Dihydroquinazolin-4(1H)-ones, an important class of heterocyclic compounds, influence numerous cellular processes. ${ }^{18}$ These exhibit a wide range of biological activities, such as antitumor, antibiotic, antidefibrillatory, antipyretic, analgesic, antihypertonic, diuretic, antihistamine, antidepressant, and vasodilating behavior. ${ }^{19}$ Furthermore, quinazolinone skeleton is frequently found in various natural products. Some examples include the anticancer compound trimetrexate, the sedative methaqualone, the alpha adrenergic receptor antagonist such as doxazosin and the antihypertensive agent ketanserin. ${ }^{20}$

Environmental problems are expected to become more serious in the 21 st century. Therefore, the development of simple, efficient, clean, high-yielding, and environmentally friendly approaches without the use of a catalyst or an organic solvent for the synthesis of these compounds is an important task for organic chemists.

In recent years, polymer composite materials with excellent thermal conductivity have attracted increasing attention. Among them, nano-sized aluminium nitride (nano-AlN) is a nontoxic, low cost substance, readily available as high purity powder. ${ }^{21}$ 


\section{Experimental}

Chemicals were purchased from Sigma-Aldrich, Fisher, and Merck. The tri/tetrasubstituted imidazole and 2,3 dihydroquinazolin- $4(1 \mathrm{H})$-one derivatives were characterized by ${ }^{1} \mathrm{H}$ and ${ }^{13} \mathrm{C}$ NMR spectra (1H NMR, 400 $\mathrm{MHz}$; $13 \mathrm{C}$ NMR, $100 \mathrm{MHz}$ ) and IR. Scanning electron microscopy (SEM) studies were conducted on a JSM 740 scanning electron microscope.

\subsection{Procedure for preparation of 2-(4-chlorophenyl) -4,5-diphenyl-1H-imidazole $1 \mathbf{a}$}

To the mixture of $0.102 \mathrm{~g}(5 \mathrm{mmol})$ of aluminum nitride, $0.140 \mathrm{~g}(1 \mathrm{mmol})$ of 4-chlorobenzaldehyde in a few drops of water $(0.3 \mathrm{~mL}), 0.210 \mathrm{~g}$ (1 mmole) benzil was added at room temperature. The reaction vessel was sealed and allowed to warm to $130^{\circ} \mathrm{C}$ for $8 \mathrm{~h}$ with constant stirring (the progress of the reaction was monitored by TLC). After completion of the reaction, the reaction mixture was cooled down to room temperature and the crude product extracted by acetone. Acetone was removed by simple evaporation. Finally, crude product 2-(4-chlorophenyl)-4,5-diphenyl-1H-imidazole $1 a$ was obtained by recrystallization from hot EtOH; yield, $0.273 \mathrm{~g}(83 \%)$.

\subsection{Procedure for preparation of 1,2-bis(4-chlorophe-} nyl)-4,5-diphenyl-1H-imidazole $2 a$

To the mixture of $0.102 \mathrm{~g}(5 \mathrm{mmol})$ of aluminum nitride, $0.140 \mathrm{~g}(1 \mathrm{mmol})$ of 4-chlorobenzaldehyde in a few drops of water $(0.3 \mathrm{~mL}), 0.210 \mathrm{~g}(1 \mathrm{mmol})$ benzil and $0.127 \mathrm{~g}(1 \mathrm{mmol})$ 4-chloroaniline were added at room temperature. The reaction vessel was sealed and allowed to warm to $130^{\circ} \mathrm{C}$ for over $8 \mathrm{~h}$ with constant stirring (the progress of the reaction was monitored by TLC). After completion of the reaction, the reaction mixture cooled down to room temperature and the crude product extracted by acetone. Acetone was removed by simple evaporation. Finally crude product 1,2-bis(4-chlorophenyl)-4,5-diphenyl-1H-imidazole 2b were obtained by recrystallization in the hot $\mathrm{EtOH}$, yield $0.316 \mathrm{~g}(72 \%)$ and M.p. $185-186^{\circ} \mathrm{C}$.

\subsection{Procedure for preparation of 2-(4-chlorophenyl) -2,3-dihydroquinazolin-4(1H)-one $3 a$}

A mixture of isatoic anhydride $(0.234 \mathrm{~g}, 1 \mathrm{mmol})$, aluminum nitride $(1.5 \mathrm{mmol})$, 4-chlorobenzaldehyde $(1 \mathrm{mmol})$ was heated at $80^{\circ} \mathrm{C}$ for $6 \mathrm{~h}$. The reaction was monitored by TLC analysis using petroleum and n-hexan-acetate $(4: 1, v / v)$. After completion of the reaction, the product was dissolved in hot ethanol, filtered and from the filtrate ethanol was removed by evaporation. Finally, crude product 2-(4-chlorophenyl)2,3-dihydroquinazolin-4(1H)-one 3a were obtained by recrystallization in the $\mathrm{EtOH}$ and water, yield $(66 \%)$.

\subsection{Characterization data of selected compounds}

2-(4-chlorophenyl)-4,5-diphenyl-1H-imidazole 1a: M.p.: 254-256 ${ }^{\circ}$ C. FT-IR-ATR $\left(v_{\max }, \mathrm{cm}^{-1}\right): 3413,3063$, 2838, 1635, 1481, 1323, 1152, 830, 695. ${ }^{1} \mathrm{H}$ NMR (400 $\left.\mathrm{MHz} \mathrm{CDCl}_{3}\right): \delta 7.87(\mathrm{~d} J=8.4 \mathrm{~Hz} 2 \mathrm{H}) 7.54(\mathrm{~d} J=$ $6.8 \mathrm{~Hz} 4 \mathrm{H}) 7.45-7.30(\mathrm{~m} 8 \mathrm{H})$ ppm. ${ }^{13} \mathrm{C}$ NMR $(100$ $\left.\mathrm{MHz} \mathrm{CDCl}_{3}\right): \delta 144.8134 .9129 .1128 .7127 .9127 .7$ $126.7 \mathrm{ppm}$.

2-(4-bromophenyl)-4,5-diphenyl-1H-imidazole $1 \boldsymbol{b}$ : M.p.: 240-244 ${ }^{\circ}$. FT-IR-ATR $\left(v_{\max }, \mathrm{cm}^{-1}\right): 3323,3061$, 2835, 1645, 1481, 1322, 827, 694. ${ }^{1} \mathrm{H}$ NMR (400 MHz, DMSO): $\delta$ 7.32-7.42 (m, 6H),7.53-7.55 (m, 4H),7.70 $(\mathrm{d}, 2 \mathrm{H}, \mathrm{J}=8.4 \mathrm{~Hz}), 8.05$ (d, 2H, J=8.4 Hz), 12.85 (br, 1H) $\mathrm{ppm}$.

2-(3-Nitrophenyl)-4,5-diphenyl-1H-imidazole 1c: M.p.: $312-314^{\circ} \mathrm{C}$. FT-IR-ATR $\left(v_{\max }, \mathrm{cm}^{-1}\right): 3383,3320$, 3069, 1695, 1524, 1348, 1070, 697.

2-(naphthalen-2-yl)-4,5-diphenyl-1H-imidazole 1d: M.p.: 267-268 ${ }^{\circ} \mathrm{C} .{ }^{1} \mathrm{H}$ NMR(400 MHz, DMSO): $\delta$ 7.26(t, $J=14,1 \mathrm{H}), 7.35(\mathrm{~m}, 2 \mathrm{H}), 7.41(\mathrm{t}, J=14 \mathrm{~Hz}, 1 \mathrm{H})$, $7.46-7.49(\mathrm{~m}, 2 \mathrm{H}), 7.55-7.62(\mathrm{~m}, 7 \mathrm{H}), 7.95-8.04(\mathrm{~m}$, $3 \mathrm{H}), 8.27(\mathrm{~d}, J=8.4 \mathrm{~Hz}, 1 \mathrm{H}), 8.63(\mathrm{~s}, 1 \mathrm{H}) \mathrm{ppm} .{ }^{13} \mathrm{C}$ NMR(100 MHz, DMSO): $\delta$ 123.9, 124.2, 126.8, 127.1, 127.2, 127.6, 128.2, 128.3, 128.6, 128.7, 128.8, 128.9, $129.2,130,131.4,133.2,133.5,135.6,137.9,138.5$, $145.9 \mathrm{ppm}$.

4,5-diphenyl-2-(p-tolyl)-1H-imidazole 1e: M.p.: 227$230^{\circ} \mathrm{C}$. FT-IR-ATR $\left(v_{\max }, \mathrm{cm}^{-1}\right): 3418,3034,29,87$, 2793, 1600, 1586, 1321, 764, ${ }^{1} \mathrm{H}$ NMR (400 MHz, $\left.\mathrm{CDCl}_{3}\right): \delta 2.43(\mathrm{~s}, 3 \mathrm{H}), 7.24-7.40(\mathrm{~m}, 8 \mathrm{H}), 7.58(\mathrm{br}, 4 \mathrm{H})$, $7.83(\mathrm{~d}, 2 \mathrm{H}, \mathrm{J}=8 \mathrm{~Hz}), 9.30(\mathrm{br}, 1 \mathrm{H}) \mathrm{ppm}$.

2,4,5-Triphenyl-1H-imidazole $\mathbf{l f}$ : $\mathrm{Mp}: \quad 259-261^{\circ} \mathrm{C}$. FT-IR-ATR $\left(v_{\max }, \mathrm{cm}^{-1}\right): 3404,3038,2962,2852$, 1601, 1408, 1071, 696.

2-(3,4-dimethoxyphenyl)-4,5-diphenyl-1H-imidazole $1 \mathrm{~g}$ : M.p.: $183-185^{\circ} \mathrm{C}$. FT-IR-ATR $\left(v_{\max }, \mathrm{cm}^{-1}\right)$ : 3055, 2937, 1602, 1484, 1263, 1024, 698. 
2-(anthracene-9-yl)-4,5-diphenyl-1H-imidazole 1h: M.p.: 219-220 ${ }^{\circ}$ C. FT-IR-ATR $\left(v_{\max }, \mathrm{cm}^{-1}\right)$ : 3381, 3048, 3069, 1598, 1443, 1342, 1079, 695. ${ }^{1} \mathrm{H}$ NMR (400 $\left.\mathrm{MHz} \mathrm{CDCl}_{3}\right): \delta 7.34-7.50(\mathrm{~m} \mathrm{10H}), 7.96(\mathrm{~d}, J=7.2$ $\mathrm{Hz}, 4 \mathrm{H}), 7.93(\mathrm{~d}, J=8.8 \mathrm{~Hz}, 2 \mathrm{H}), 8.02(\mathrm{~d}, J=8.4$ $\mathrm{Hz}, 2 \mathrm{H}), 8.50(\mathrm{~s}, 1 \mathrm{H}), 9.87(\mathrm{~b}, 1 \mathrm{H}) \mathrm{ppm} .{ }^{13} \mathrm{C}$ NMR $\left(100 \mathrm{MHz}, \mathrm{CDCl}_{3}\right): \delta 143.6,131.5,131.1,129,128.6$, $128.5,127.9,127.5,126.6,125.8,125.4,125 \mathrm{ppm}$.

5-bromo-2-(4,5-diphenyl-1H-imidazol-2-yl)phenol 1i: M.p: 221-224 ${ }^{\circ} \mathrm{C}$. FTIR $\left(\mathrm{KBr}, \mathrm{cm}^{-1}\right): 3417,3392,3210$, 2680, 1644, 1487, 712.

2-(4-methoxyphenyl)-4,5-diphenyl-1H-imidazole 1j: M.p.: 221-224 ${ }^{\circ} \mathrm{C}$. FTIR $\left(\mathrm{KBr}, \mathrm{cm}^{-1}\right)$ : 3034, 2987, 1600, 1321, 1261, 764. ${ }^{1} \mathrm{H}$ NMR (400 MHz, DMSO): $\delta 3.82$ (s, 3H), $7.06(\mathrm{~d}, \mathrm{~J}=8.8 \mathrm{~Hz}, 2 \mathrm{H}), 7.37(\mathrm{~m}, 6 \mathrm{H}), 7.52(\mathrm{~d}$, $\mathrm{J}=6.4 \mathrm{~Hz}, 4 \mathrm{H}), 8.03(\mathrm{~d}, \mathrm{~J}=8.8 \mathrm{~Hz}, 2 \mathrm{H}), 12.5(\mathrm{br}, 1 \mathrm{H})$ ppm. ${ }^{13} \mathrm{C}$ NMR (100 MHz, DMSO): $\delta$ 55.6, 114.6, $123.2,127.3,127.7,128.2,128.9,146.2,159.9$ ppm.

1-(4-chlorophenyl)-2-(4-chlorophenyl)-4,5-diphenyl-1Himidazole 2a: Isolated Yield $=72 \%$. M.p.: 185$186^{\circ} \mathrm{C} .{ }^{1} \mathrm{H}-\mathrm{NMR}\left(\mathrm{CDCl}_{3}, 400 \mathrm{MHz}\right) ; \delta 6.99(\mathrm{~d}, 2 \mathrm{H}$, $\mathrm{J}=8.4), 7.14-7.16(\mathrm{~m}, 2 \mathrm{H}), 7.23-7.33(\mathrm{~m}, 10 \mathrm{H}), 7.39(\mathrm{~d}$, $2 \mathrm{H}, J=8.8), 7.61$ (d, 2H, $J=8.4) \mathrm{ppm}$.

1-benzyl-2-(4-chlorophenyl)-4,5-diphenyl-1H-imidazole 2b: M.p.: $161-164^{\circ} \mathrm{C}$. FTIR $\left(\mathrm{KBr}, \mathrm{cm}^{-1}\right)$ : 3059 , 3030, 2938, 1662, 1446, 1085, 693.

1-benzyl-2-(4-bromophenyl)-4,5-diphenyl-1H-imidazole 2c: M.p.: $162-165^{\circ} \mathrm{C}$. FTIR $\left(\mathrm{KBr}, \mathrm{cm}^{-1}\right)$ : 3055, 1597, 1496, 1071, 694.
3-(1-benzyl-4,5-diphenyl-1H-imidazol-2-yl)phenol 2d: M.p.: $229-231^{\circ} \mathrm{C}$. FTIR $\left(\mathrm{KBr}, \mathrm{cm}^{-1}\right)$ : 3059, 3031, 1598, 1457, 1234, 695.

1-benzyl-2-(3,4-dimethoxyphenyl)-4,5-diphenyl-1H-imidazole 2e: M.p.: $161-163^{\circ} \mathrm{C}$. FTIR $\left(\mathrm{KBr}, \mathrm{cm}^{-1}\right)$ : 3322, 3052, 3001, 1602, 1529, 1484, 1263, 698.

1-benzyl-2-(2-nitrophenyl)-4,5-diphenyl-1H-imidazole 2f: $\quad$ M.p.: $144-148^{\circ} \mathrm{C}$. FTIR $\left(\mathrm{KBr}, \mathrm{cm}^{-1}\right)$ : 3059, 3031, 2925, 1602, 1497, 1300, 1076, 692.

2-(4-bromophenyl)-1,4,5-triphenyl-1H-imidazole $2 \mathrm{~g}$ : M.p.: $179-183^{\circ} \mathrm{C}$. FTIR $\left(\mathrm{KBr}, \mathrm{cm}^{-1}\right)$ : 3055,1597 , 1477, 1446, 1071, 831, 694.

1,4,5-triphenyl-2-(p-tolyl)-1H-imidazole 2h: M.p.: 175$178^{\circ} \mathrm{C}$. FTIR $\left(\mathrm{KBr}, \mathrm{cm}^{-1}\right)$ : 3042, 2919, 1595, 1414, 1024, 695.

2-(4-chlorophenyl)-1,4,5-triphenyl-1H-imidazole $2 \boldsymbol{i}$ : M.p.: $172-174^{\circ} \mathrm{C}$. FTIR $\left(\mathrm{KBr}, \mathrm{cm}^{-1}\right)$ : 3060, 1597 , 1496, 1446, 1082, 837, 698.

4-(1,4,5-Triphenyl-1H-imidazol-2-yl)-phenol 2j: M.p.: 279-280 ${ }^{\circ}$. FTIR $\left(\mathrm{KBr}, \mathrm{cm}^{-1}\right): 3448,3057,2974$, 2613, 1604, 1492, 1273, 696.

2-(4-chlorophenyl)-2,3-dihydroquinazolin-4(1H)-one 3a: M.p.: $204-207^{\circ} \mathrm{C} .{ }^{1} \mathrm{H}$ NMR $(250 \mathrm{MHz}$, DMSO$\left.d_{6}\right): \delta 8.29(\mathrm{~s}, 1 \mathrm{H}), 7.61-7.41(\mathrm{~m}, 5 \mathrm{H}), 7.26-7.2(\mathrm{t}$, $1 \mathrm{H}), 7.12(\mathrm{~s}, 1 \mathrm{H}), 6.75-6.63(\mathrm{~m}, 2 \mathrm{H}), 5.75(\mathrm{~s}, 1 \mathrm{H}) \mathrm{ppm}$. ${ }^{13} \mathrm{C}$ NMR $\left(62 \mathrm{MHz}, \mathrm{DMSO}-d_{6}\right): \delta 163.9,148.1,141.1$,

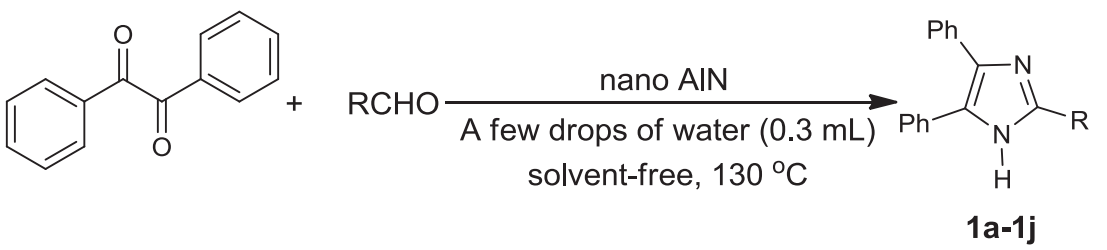

Scheme 1. Synthesis of 2,4,5-trisubstituted imidazoles.

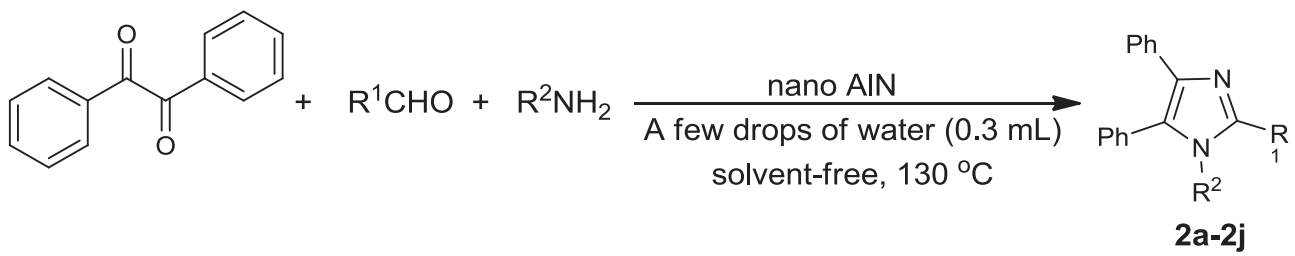

Scheme 2. Synthesis of 1,2,4,5-tetrasubstituted imidazoles. 
$133.8,133.4,129.2,128.7,127.8,117.7,115.4,114.9$, $66.2 \mathrm{ppm}$.

2-(4-methylphenyl)-2,3-dihydroquinazolin-4(1H)-one 3d: M.p.: $220-225^{\circ} \mathrm{C} .{ }^{1} \mathrm{H}$ NMR $(250 \mathrm{MHz}$, DMSO$d 6): \delta 8.21(\mathrm{~s}, 1 \mathrm{H}), 7.62-7.59(\mathrm{~d}, 1 \mathrm{H}), 7.38-7.35(\mathrm{~d}$, $2 \mathrm{H}), 7.26-7.16(\mathrm{~m}, 3 \mathrm{H}), 7.03(\mathrm{~s}, 1 \mathrm{H}), 6.75-6.63(\mathrm{~m}$, $2 \mathrm{H}), 5.71(\mathrm{~s}, 1 \mathrm{H}), 2.49-2.42(\mathrm{~s}, 3 \mathrm{H}) \mathrm{ppm} .{ }^{13} \mathrm{C} \mathrm{NMR}$ (62 MHz, DMSO- $d 6$ ): $\delta$ 164.1, 148.4, 139.1, 138.2, $133.7,129.3,127.8,127.2,117.5,115.4,114.9,66.8$, $21.2 \mathrm{ppm}$.

\section{Results and Discussion}

In continuing our investigations on the synthetic organic reactions, ${ }^{22-25}$ in efforts to develop an efficient procedure for the synthesis of substituted imidazole and quinazolin-4(1H)-one derivatives, we report the synthesis of tri/tetrasubstituted imidazole and quinazolin$4(1 \mathrm{H})$-ones, via one-pot and multi-component condensation using aluminium nitride under solvent-free or water as solvent conditions.

It was found that benzil could be condensed with aromatic aldehydes and nano aluminum nitride to smoothly afford 2,4,5-trisubstituted-1H-imidazole derivatives, $\mathbf{1 a}-\mathbf{1} \mathbf{j}$ with excellent yields at $80^{\circ} \mathrm{C}$ under solvent-free condition in the presence a few drops of water $(0.3 \mathrm{~mL})$ (scheme 1$)$. The same reaction with an additional amine yielded 1,2,4,5-tetrasubstituted-1 $H$ imidazole derivatives $\mathbf{2 a - 2} \mathbf{j}$ (scheme 2).

Table 1. Optimization of reaction time ${ }^{\mathrm{a}}$.

\begin{tabular}{lccc}
\hline Entry & AlN (mmol) & Time (h) & Yield (\%) \\
\hline 1 & 4 & 3 & 10 \\
2 & 4 & 5 & 50 \\
3 & 5 & 6 & 68 \\
4 & 4 & 8 & 69 \\
5 & 5 & 8 & 83
\end{tabular}

${ }^{a}$ Molar ratio of the reagents: 4-chlorobenzaldehyde $1 \mathrm{mmol}$, benzyl $1 \mathrm{mmol}$.

${ }^{\mathrm{b}}$ Isolated yield.
Initially, the effect of reaction time on the yield was investigated (table 1, entry 1-5). The reaction took place quickly at first and gradually reached the balance after $8 \mathrm{~h}$. The yield changed little after $8 \mathrm{~h}$. Also, the effect of reaction time on the condensation, a one-pot reaction of isatoic anhydride, aldehyde and aluminum nitride for the synthesis of substituted quinazolin-4(1H)-ones, ${ }^{32,33}$ 3a-3e in water was investigated (scheme 3 ). When reaction time was increased gradually from 3 to $6 \mathrm{~h}$, the rate of the reaction increased from 2 to $63 \%$. Increase of time to $7 \mathrm{~h}$ has less effect on the yield $(66 \%)$ of the reaction.

We carried out the study in search for optimal amount of aluminum nitride for the proposed transformation using as a model the reaction involving $1 \mathrm{mmol}$ of 4-chlorobenzaldehyde, $1 \mathrm{mmol}$ of benzil for 2,4,5trisubstitution and also $1 \mathrm{mmol}$ of 4-chloroaniline for synthesis of 1,2,4,5-tetrasubstituted imidazole derivatives in the presence of different amounts of nano aluminum nitride in few drops of water $(0.3 \mathrm{~mL})$ at $130^{\circ} \mathrm{C}$ was conducted, and the significant data obtained as a function of the amount of aluminum nitride are shown in (figure 1, 1a and 2b). The best results were obtained with $5 \mathrm{mmol}$ of aluminum nitride in the presence of a few drops of water $(0.3 \mathrm{~mL})$ and under solvent-free conditions after $8 \mathrm{~h}$.

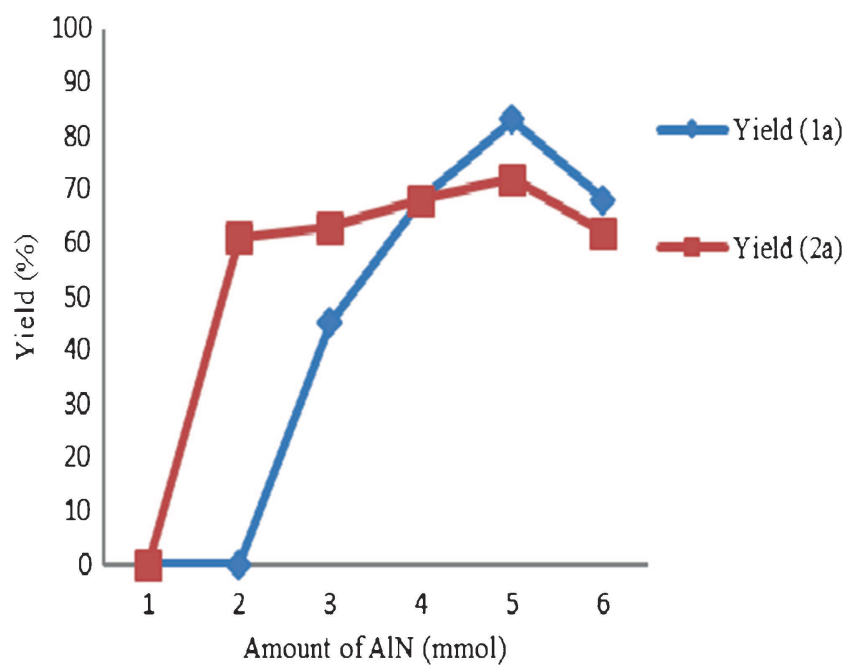

Figure 1. Optimization of the amount of aluminum nitride for the synthesis of substituted imidazole.<smiles>[R]C1NC(=O)c2ccccc2N1</smiles>

Scheme 3. Synthesis of substituted quinazolin-4(1H)-ones. 


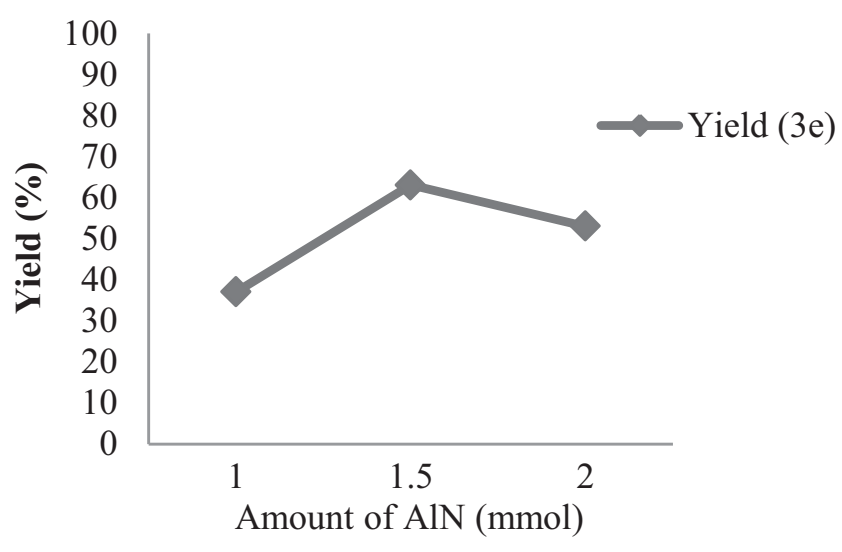

Figure 2. Optimization of the amount of aluminum nitride for the synthesis of substituted quinazolin-4(1H)-ones.

In order to study we optimized the synthesis of substituted quinazolin-4(1H)-ones with various amount (mmol) of nano AlN. The condensation, a one-pot reaction of isatoic anhydride (1 mmol), 3-nitrobenzaldehyde (1 mmol) was chosen as a model reaction (figure 1 ).

Aluminum nitride plays a major role in the product yield. It was observed that increasing the loading of the nano AlN from 1 to $1.5 \mathrm{mmol}$ gave an improved yield of $63 \%$ of the product (figures 2, 3e). Further increase of aluminum nitride loading leads to lower reaction yields.
Under optimized conditions for aluminum nitride, the scope of synthesis of 2,4,5-trisubstituted imidazole derivatives with other aldehydes was found to be quite good. As shown in (table 2), the method has the ability to tolerate a variety of functional groups such as chloro, nitro, methoxy and methyl.

Then, under these conditions, 1,2,4,5-tetrasubstituted imidazole derivatives were formed cleanly, The results (table 3) clearly indicate the feasibility of four-component reaction. The products were synthesized in good yield and a variety of different substituted aldehydes and amines were subjected to this reaction.

The optimized reaction conditions were extended to the condensation of other aldehydes with isatoic anhydride and aluminum nitride at $80^{\circ} \mathrm{C}$. Aromatic aldehydes bearing both electron-deficient and electron-rich substituents afforded the desired 2,3-disubstituted dihydroquinazolin-4 $(1 \mathrm{H})$-one in good yields (table 4 ).

Major advantage of this protocol is the simplicity of operation and isolation of the products, which have been achieved by simple washing and crystallization of the crude products.

The scanning electron microscope (SEM) images of nano aluminium nitride showed that the resulting particles were irregular sphere structure with the particle size is about $40 \mathrm{~nm}$ (figure $3 \mathrm{a}$ ). In the presence of water, the nano AlN will be decomposed to form

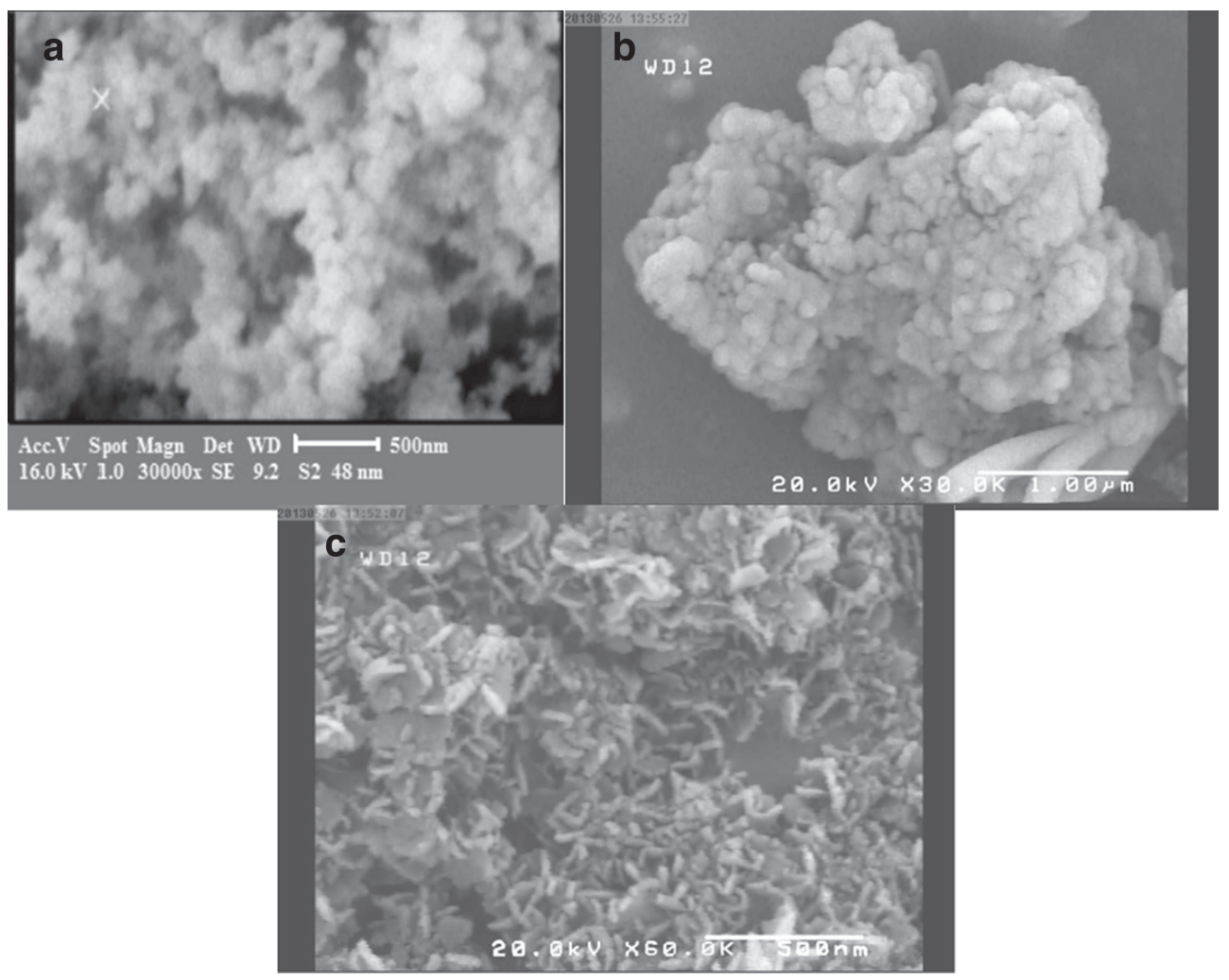

Figure 3. SEM images: (a) nano $\mathrm{AlN}$, (b) nano $\mathrm{AlN}$ in reaction and (c) $\mathrm{Al}(\mathrm{OH})_{3}$ after reaction. 
Table 2. Synthesis of 2,4,5-trisubstituted imidazole derivatives ${ }^{\mathrm{a}}$.

\begin{tabular}{lcccc}
\hline Entry & $\mathrm{R}$ & Product & Yield $^{\mathrm{b}}(\%)$ & $\mathrm{Mp}\left({ }^{\circ} \mathrm{C}\right)$ found (reported) \\
\hline 1 & $4-\mathrm{ClC}_{6} \mathrm{H}_{4}$ & $1 \mathrm{a}$ & 83 & $254-256(259-269)^{26}$ \\
2 & $4-\mathrm{BrC}_{6} \mathrm{H}_{4}$ & $1 \mathrm{~b}$ & 70 & $240-244(252-254)^{26}$ \\
3 & $3-\mathrm{NO}_{2} \mathrm{C}_{6} \mathrm{H}_{4}$ & $1 \mathrm{c}$ & 79 & $312-314(315-317)^{27}$ \\
4 & $\mathrm{C}_{10} \mathrm{H}_{7}$ & $1 \mathrm{~d}$ & 80 & $267-268(273-276)^{28}$ \\
5 & $4-\mathrm{CH}_{3} \mathrm{C}_{6} \mathrm{H}_{4}$ & $1 \mathrm{e}$ & 74 & $227-230(226-228)^{26}$ \\
6 & $\mathrm{C}_{6} \mathrm{H}_{5}$ & $1 \mathrm{f}$ & 72 & $259-261(267-269)^{29}$ \\
7 & $3,4-\left(\mathrm{OCH}_{3}\right)_{2} \mathrm{C}_{6} \mathrm{H}_{3}$ & $1 \mathrm{~g}$ & 80 & $183-185(215)^{6}$ \\
8 & $\mathrm{C}_{14} \mathrm{H}_{9}$ & $1 \mathrm{~h}$ & 98 & $219-220$ \\
9 & $5-\mathrm{Br}_{2}-\mathrm{OHC}_{6} \mathrm{H}_{3}$ & $1 \mathrm{i}$ & 86 & $311-314(186-187)^{29}$ \\
10 & $4-\mathrm{OCH}_{3} \mathrm{C}_{6} \mathrm{H}_{4}$ & $1 \mathrm{j}$ & 84 & $221-224(228-231)^{26}$
\end{tabular}

${ }^{a}$ Molar ratio of the reagents: aluminum nitride/aldehyde/benzil $(5 \mathrm{mmol} / 1 \mathrm{mmol}$ $/ 1 \mathrm{mmol})$.

${ }^{\mathrm{b}}$ Isolated yield.

Table 3. Synthesis of 1,2,4,5-tetrasubstituted imidazole derivatives ${ }^{\mathrm{a}}$.

\begin{tabular}{lccccc}
\hline Entry & $\mathrm{R}^{1}$ & $\mathrm{R}^{2}$ & Product & Yield $(\%)^{\mathrm{b}}$ & $\mathrm{Mp}\left({ }^{\circ} \mathrm{C}\right)$ found (reported) \\
\hline 1 & $4-\mathrm{ClC}_{6} \mathrm{H}_{4}$ & $4-\mathrm{ClC}_{6} \mathrm{H}_{4}$ & $2 \mathrm{a}$ & 72 & $185-186(187-189)^{14}$ \\
2 & $4-\mathrm{ClC}_{6} \mathrm{H}_{4}$ & $\mathrm{C}_{6} \mathrm{H}_{5} \mathrm{CH}_{2}$ & $2 \mathrm{~b}$ & 77 & $161-164(161-163)^{29}$ \\
3 & $4-\mathrm{BrC}_{6} \mathrm{H}_{4}$ & $\mathrm{C}_{6} \mathrm{H}_{5} \mathrm{CH}_{2}$ & $2 \mathrm{c}$ & 83 & $162-165(172-175)^{16}$ \\
4 & $3-\mathrm{OHC}_{6} \mathrm{H}_{4}$ & $\mathrm{C}_{6} \mathrm{H}_{5} \mathrm{CH}_{2}$ & $2 \mathrm{~d}$ & 93 & $229-231(232-235)^{3}$ \\
5 & $3,4-\left(\mathrm{OCH}_{3}\right)_{2} \mathrm{C}_{6} \mathrm{H}_{3}$ & $\mathrm{C}_{6} \mathrm{H}_{5} \mathrm{CH}_{2}$ & $2 \mathrm{e}$ & 93 & $161-163$ \\
6 & $2-\mathrm{NO}_{2} \mathrm{C}_{6} \mathrm{H}_{4}$ & $\mathrm{C}_{6} \mathrm{H}_{5} \mathrm{CH}_{2}$ & $2 \mathrm{f}$ & 81 & $144-148(152-155)^{30}$ \\
7 & $4-\mathrm{BrC}_{6} \mathrm{H}_{4}$ & $\mathrm{C}_{6} \mathrm{H}_{5}$ & $2 \mathrm{~g}$ & 70 & $179-183(191-193)^{6}$ \\
8 & $4-\mathrm{CH}_{3} \mathrm{C}_{6} \mathrm{H}_{4}$ & $\mathrm{C}_{6} \mathrm{H}_{5}$ & $2 \mathrm{~h}$ & 71 & $175-178(187-189)^{25}$ \\
9 & $2-\mathrm{ClC}_{6} \mathrm{H}_{4}$ & $\mathrm{C}_{6} \mathrm{H}_{5}$ & $2 \mathrm{i}$ & 76 & $172-174(160-162)^{10}$ \\
10 & $4-\mathrm{OHC}_{6} \mathrm{H}_{4}$ & $\mathrm{C}_{6} \mathrm{H}_{5}$ & $2 \mathrm{j}$ & 81 & $279-280(280-281)^{10}$
\end{tabular}

${ }^{a}$ Molar ratio of the reagents: aluminum nitride/aldehyde/amine/benzil $(5 \mathrm{mmol} / 1$ $\mathrm{mmol} / 1 \mathrm{mmol} / 1 \mathrm{mmol}$ ).

${ }^{\mathrm{b}}$ Isolated yield.

Table 4. Synthesis of 2,3- dihydroquinazolin-4(1H)-one derivatives ${ }^{\mathrm{a}}$.

\begin{tabular}{lcccc}
\hline Entry & $\mathrm{R}$ & Product & Yield $^{\mathrm{b}}(\%)$ & M.p. $\left({ }^{\circ} \mathrm{C}\right)$ found (reported) \\
\hline 1 & $4-\mathrm{ClC}_{6} \mathrm{H}_{4}$ & $3 \mathrm{a}$ & 66 & $204-207(205-2206)^{31}$ \\
2 & $3-\mathrm{NO}_{2} \mathrm{C}_{6} \mathrm{H}_{4}$ & $3 \mathrm{~b}$ & 73 & $213-216(216-217)^{31}$ \\
3 & $4-\mathrm{OCH}_{3} \mathrm{C}_{6} \mathrm{H}_{4}$ & $3 \mathrm{c}$ & 66 & $189-193(192-193)^{31}$ \\
4 & $4-\mathrm{CH}_{3} \mathrm{C}_{6} \mathrm{H}_{4}$ & $3 \mathrm{~d}$ & 62 & $220-225(223-224)^{31}$ \\
5 & $\mathrm{C}_{6} \mathrm{H}_{5}$ & $3 \mathrm{e}$ & 63 & $218-222(218-219)^{31}$
\end{tabular}

${ }^{\mathrm{a}}$ Molar ratio of the reagents: aluminum nitride/aldehyde/isatoic anhydride $(1.5 \mathrm{mmol} / 1$ $\mathrm{mmol} / 1 \mathrm{mmol}$ ).

${ }^{\mathrm{b}}$ Isolated yield.

aluminum hydroxide and ammonia. These particles are connected with each other without obvious boundaries. SEM image showed that diameters of the particles in the reaction mixture are approximately $1 \mu \mathrm{m}$ (figure $3 \mathrm{~b}$ ). After the reaction, the particle size increased and the average size of amorphous aluminum hydroxide is in the range of $500 \mathrm{~nm}$ (figure 3c).
According to the results, the reaction can be mechanistically considered as aluminum nitride generating a solution of ammonia by reaction with water (scheme 4). Based on this mechanism, the $\operatorname{Al}(\mathrm{OH})_{3}$ as a Lewis acid participates in the reaction which activates the aldehydes, benzil and isatoic anhydride followed by nucleophilic addition of amines. 

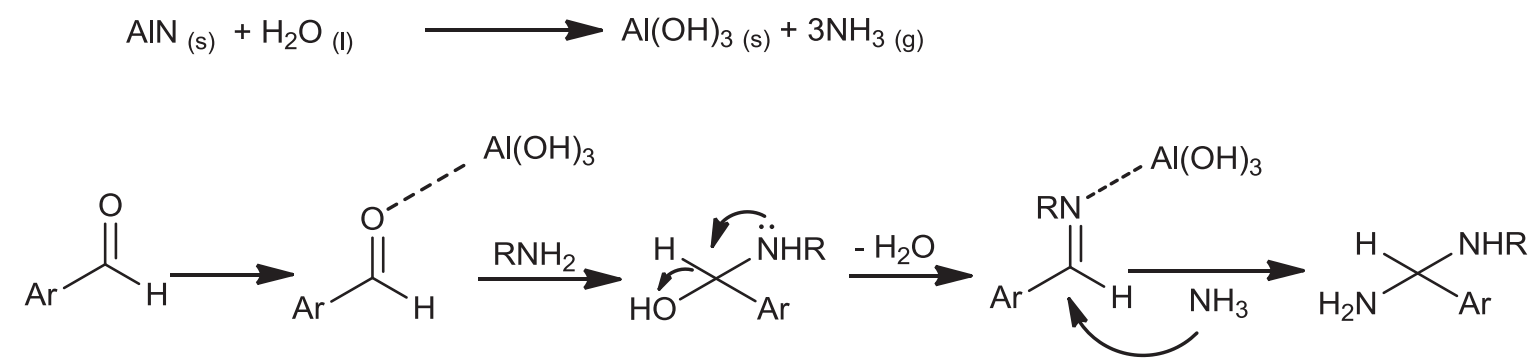

$\mathrm{R}=\mathrm{H}$, Alkyl or Aryl

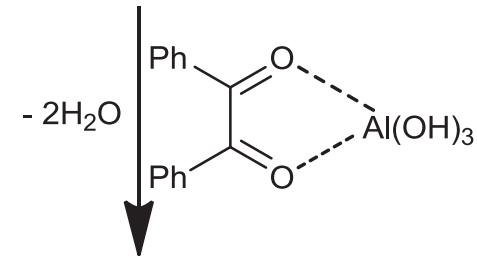<smiles>[R]n1c([Al]C)nc(-c2ccccc2)c1-c1cccnc1-c1ccccc1</smiles>

Scheme 4. Possible mechanism.

\section{Conclusion}

In conclusion, we have developed a new strategy that provides an efficient way for the synthesis of tri/tetrasubstituted-1H imidazoles and 2,3-dihydroquinazolin$4(1 \mathrm{H})$-ones using nano AlN as a source of ammonia. Our method involves mild reaction conditions, very simple and accessible starting materials. The key advantages of this process are high yields, elimination of organic solvents and catalysts, easy work-up and purification of products by non-chromatographic methods.

\section{Supplementary Information}

Additional information pertaining to characterization of the tri/tetrasubstituted imidazole and 2,3 dihydroquinazolin-4(1H)-one derivatives, namely, IR spectra, ${ }^{1} \mathrm{H}$ and ${ }^{13} \mathrm{C}$ NMR spectra are available at www.ias.ac. in/chemsci.

\section{Acknowledgements}

The authors acknowledge Ilam University, Ilam, Iran for financial support of this work.

\section{References}

1. Xing X, Zhu X, Li H, Jiang Y and Ni J 2012 Chemosphere 86368

2. Mohammadizadeh M R, Hasaninejad A and Bahramzadeh M 2009 Synth. Commun. 393232
3. Niknam K, Deris A, Naeimi F and Majleci F 2011 Tetrahedron Lett. 524642

4. Li W and Lam Y 2005 J. Comb. Chem. 7644

5. Karimi A R, Alimohammadi Z and Amini M M 2010 Mol. Divers. 14635

6. Das B, Kashanna J, Kumar R A and Jangili P 2013 Monatsh Chem. 144223

7. Heravi M M, Derikvand F and Haghighi M 2008 Monatsh Chem. 13931

8. Shaterian H R and Ranjbar M J 2011 Mol. Liq. 16040

9. Nagarapu L, Apuri S and Kantevari S 2007 J. Mol. Catal. A: Chem. 266104

10. Kantevari S, Vuppalapati S V N, Biradar D O and Nagarapu L 2007 J. Mol. Catal. A: Chem. 266109

11. Karimi-Jaberi Z and Barekat M 2010 Chin. Chem. Lett. 211183

12. Heravi M M, Derikvand F and Bamoharram F F $2007 \mathrm{~J}$. Mol. Catal. A: Chem. 263112

13. Sharma S D, Hazarika P and Konwar D 2008 Tetrahedron Lett. 492216

14. Davoodnia A, Heravi M M, Safavi-Rad Z and TavakoliHoseini N 2010 Synth. Commun. 402588

15. Hekmat Shoar R, Rahimzadeh G, Derikvand F and Farzaneh M 2010 Synth. Commun. 401270

16. Emrani A, Davoodnia A and Tavakoli-Hoseini N 2011 Bull. Korean Chem. Soc. 322385

17. Teimouria A and Najafi A $2011 \mathrm{~J}$. Mol. Catal. A: Chem. 34639

18. Murthy P, Rambabu D, Krishna G R, Reddy C M, Prasad K R S, Basaveswara Rao M V and Pal M 2012 Tetrahedron Lett. 536923

19. Subba Reddy B V, Venkateswarlu A, Madan C and Vinu A 2011 Tetrahedron Lett. 521891

20. Vilas B L, Shinde P V and Shingare M S 2013 Tetrahedron Lett. $\mathbf{5 4} 5778$ 
21. Yu J H, Duan J K, Peng W Y, Wang L C, Peng P and Jiang P K 2011 Polymer Lett. 5132

22. Ghorbani-Choghamarani A, Zolfigol M A, Salehi P, Ghaemi E, Madrakian E, Nasr-Isfahanid $\mathrm{H}$ and Shahamirian M 2008 Acta Chim. Slov. 55644

23. Ghorbani-Choghamarani A and Taghipour T 2011 Lett. Org. Chem. 8470

24. Ghorbani-Choghamarani A, Nikoorazm M, Goudarziafshar H, Shokr A and Almasi H 2011 J. Chem. Sci. 123 453

25. Ghorbani-Choghamarani A, Zolfigol M A, Hajjami M, Goudarziafshar H, Nikoorazm M, Yousefi S and Tahmasbi B 2011 J. Brazil. Chem. Soc. 22525

26. Shaabani A and Rahmati A 2006 J. Mol. Cat. A: Chem. 249246
27. Acke D, Orru R and Stevens C 2006 Qsar. Comb. Sci. 25474

28. Safari J, Dehghan Khalili S and Banitaba S H 2011 Synthetic Commun. 412359

29. Samai S, Nandi G, Singh P and Singh M S 2009 Tetrahedron $\mathbf{6 5} 10155$

30. Sadeghi B, Mirjalili B B F and Hashemi M 2008 Tetrahedron Lett. 492575

31. Rostami A and Tavakoli A 2011 Chin. Chem. Lett. 22 1320

32. Wang M, Zhang T T, Liang Y and Gao J J 2011 Chin. Chem. Lett. 221423

33. Kanhe N S, Tekale S U, Kulkarni N V, Nawale A B, Das A K, Bhoraskar S V, Ingle R D and Pawar R P 2012 J. Iran. Chem. Soc. 10243 